netzungsstörungen. Dieses dann einsetzende adaptive Immunsystem wird durch 2 Substanzklassen gesteuert: die Androgene und die Cytokine.

Androgene wirken über eine Molekül-Rezeptor-Interaktion. Es gibt einen langsam verlaufenden genomischen Reaktionsweg mit Proteinbiosynthese und einen nicht-genomischen Mechanismus an der Zellmembran. Meßgrößen des Androgen-Metabolismus sind das Androgen-Rezeptor-Protein, die Androgen-Rezeptor-mRNA und als Leitenzym die 5 $\alpha$-Reductase. Alle Meßgrößen sind mittlerweile im Tränendrüsenepithel und in den Meibom-Drüsen nachgewiesen. Damit ist die Augenoberfläche als Zielstruktur der Androgene belegt. Durch systemische Androgengabe lässt sich experimentell eine histologische Veränderung der Tränendrüse erreichen. Desgleichen verändert sich der wässrig-mucinöse und der lipidhaltige Anteil der Träne unter Androgeneinfluss. Androgene bewirken eine Down-Regulierung mehrerer immunologischer Prozesse. Patientinnen mit Hirsutismus klagen aufgrund des protektiven Einflusses dieser Hormone auf den Tränenfilm entsprechend weniger häufig über SiccaBeschwerden.

Die Cytokine sind eine heterogene Gruppe unterschiedlicher Entzündungsmediatoren. Hierzu zählen Interleukine,
Tumor-Nekrose-Faktoren, Interferone und Wachstumsfaktoren. Cytokine funktionieren innerhalb eines Netzwerks mit Interleukin 1 und Tumor-Nekrose-Faktor $\alpha$ als Regulatorproteinen. Die Redundanz gleichartiger Wirkungsweisen macht beispielsweise Interleukin $1 \alpha$, Interleukin $1 \beta$ und TumorNekrose-Faktor $\alpha$ ununterscheidbar. Zudem werden Cytokine simultan an mehreren Orten im Organismus mit unterschiedlicher Wirkung aktiv (Pleiotropie). Daneben gibt es lokal vermittelte rezeptor-abhängige Effekte. An der Augenoberfläche sind die Cytokine im Modell der experimentellen Wundheilung untersucht. Klinisch lassen sich derzeit Wachstumsfaktoren über autologes Serum an der Augenoberfläche anwenden. Ausserdem steht mit dem Cyclosporin A ein Präparat zur Verfügung, welches Interleukin 2 inhibiert und daneben TLymphozyten, Makrophagen und Monozyten blockiert.

Mit der Kenntnis beider Stufen der Abwehrreaktion am Auge bieten sich neue Möglichkeiten, diese therapeutisch zu beeinflussen.

Korrespondenz; Dr. Thomas Kaercher, Augenklinik des Städtischen Klinikums Ludwigshafen, Bremserstraße 79, D-67063 Ludwigshafen, E-Mail: kaerchet@klilu.de.

\title{
Immune modulated inflammation of the ocular surface - a change of paradigm in the understanding of dry eye disease
}

\author{
N. Knop and E. Knop \\ Department of Cell Biology in Anatomy, Hannover Medical School, D-30625 Hannover, Germany
}

Introduction: Dry eye disease reflects a disruption of the functional anatomy of the ocular surface and can be caused by various influences including immune mediated inflammation.

Methods: A literature review was performed to characterize the causative factors involved in arise and progression of inflammatory events at the ocular surface in dry eye disease.

Results: The understanding of the pathogenesis of dry eye disease has proceeded from a focus on tear deficiency to a consideration of tear quality and to the concept of wetting of the ocular surface. Immune based inflammation represents a newly discovered phenomenon that is involved as a primary or secondary pathogenetic factor in several forms of dry eye disease. The physiological eye-associated lymphoid tissue (EALT) of the ocular surface can be of potential regulatory importance. Immune based inflammation is caused by the production of inflammatory cytokines due to wounding of the ocular surface. It can reinforce maldifferentiation of the surface epithelia, diminished secretion and defects in wettability and it can result in a vicious circle of ocular surface destruction. The susceptibility of ocular surface inflammation is increased by a lack of androgen in ocular tissues.

Conclusion: Immune based inflammation represents an important new approach to the understanding of dry eye disease and is able to cause a negative feedback on protective mechanisms of the ocular surface. 